\title{
WINTER METABOLISM IN DECIDUOUS TREES: MECHANISMS, GENES AND ASSOCIATED PROTEINS
}

\author{
METABOLISMO INVERNAL EN ÁRBOLES CADUCIFOLIOS: MECANISMOS, GENES Y \\ PROTEÍNAS ASOCIADAS
}

\author{
Mónica L. García Bañuelos ${ }^{1}$, Luz Vázquez Moreno², Joy Winzerling ${ }^{4}$, J. Antonio Orozco ${ }^{3}$ and Alfonso A. Gardea ${ }^{3 *}$ \\ ${ }^{1}$ Centro de Investigación en Alimentación y Desarrollo (CIAD), A. C. Unidad Delicias. Ave Cuarta Sur 3820 Fracc.Vencedores del Desierto. 33089, Deli- \\ cias Chih. ${ }^{2}$ Coordinación de Ciencia de Alimentos, CIAD. Apartado Postal 1735. 83000, Hermosillo, Son. Tel./Fax: 526622892400 x-304. ${ }^{3}$ CIAD, Uni- \\ dad Guaymas. Carretera Varadero Nacional km 6.6. 85400, Guaymas, Son. ${ }^{4}$ Department of Nutritional Sciences, University of Arizona, Tucson, Arizona, \\ USA.
}

*Autor para correspondencia (gardea@ciad.mx)

\section{SUMMARY}

Plants vary greatly in their ability to survive cold temperatures; some may withstand extreme freezing conditions, while others will be irreversibly injured at temperatures above freezing. The maximum freezing tolerance of plants is induced in response to environmental signals. Temperate woody trees need to acclimate to survive the cold winter. Trees have evolved a complex dynamic process controlling the development of dormancy and cold hardiness that synchronize accurately the onset and termination of winter metabolism. Only recently has been obtained progress in elucidating the molecular mechanisms of dormancy and freezing tolerance development in woody plants, and emerging disciplines are opening a wide horizon for future studies. The purpose of this review is to highlight recent developments indicating that cold-responsive genes and proteins contribute to freezing tolerance during winter in woody plants.

Index words: Cold hardiness, acclimation, deacclimation, dormancy, genetic control.

\section{RESUMEN}

Las plantas varían grandemente en su habilidad para sobrevivir temperaturas frías; mientras algunas pueden soportar condiciones de congelación extrema, otras son dañadas irreversiblemente por temperaturas apenas arriba del punto de congelamiento. La máxima tolerancia de plantas al congelamiento, es inducida en respuesta a señales ambientales. Los árboles de la zona templada necesitan aclimatarse para sobrevivir al frío invernal; han evolucionado un complejo proceso dinámico que controla el desarrollo del reposo y la resistencia al frío, al sincronizar con precisión el inicio y terminación del metabolismo invernal. Sólo recientemente ha habido progreso en elucidar los mecanismos moleculares del reposo y la resistencia al frío en plantas leñosas, $y$ las disciplinas emergentes abren un amplio horizonte para futuros estudios. El propósito de esta revisión en plantas leñosas fue resaltar los desarrollos recientes que señalan la contribución de los genes y proteínas de respuesta al frío a su tolerancia al congelamiento durante el invierno.

Palabras clave: Resistencia al frío, aclimatación, desaclimatación, reposo, control genético.

\section{INTRODUCTION}

Low temperature (LT) is one of the most important abiotic factors limiting growth, productivity and distribution of plants. LT decreases biosynthetic activity inhibits the normal function of physiological processes and may cause permanent injuries, which finally lead to death (Tomashow, 1999; Wisniewski et al., 2004; Puhakainen, 2004a, b).

Plant species vary widely in their ability to tolerate LT. Chilling-sensitive tropical species can be irreparably damaged even by non-freezing temperatures. Injuries are due to an overall impairment of metabolic and cellular processes and alterations in membrane properties. Chilling-tolerant -but freezing sensitive- plants are able to survive temperatures slightly below zero, but become severely damaged upon ice formation in their tissues. Freezing-tolerant plants, like some woody trees and shrubs, are able to survive variable levels of freezing, the actual degree of tolerance being dependent upon the species, developmental stage and duration of stress (Gusta et al., 2005; Welling and Palva, 2006).

Understanding how these woody plants survive such freezing temperatures is not only a scientific challenge, but also has important economic implications. Increasing evidence of multiple functions for stress-induced proteins in overwintering plants confirms the need for a global approach in the analysis of adaptive mechanisms. From this perspective, the valorization of rapidly increasing knowledge on the molecular and genetic basis of plants responses to cold, demand multidisciplinary collaborations. Climate changes also need to be taken into account to identify the adaptive traits that agricultural and forest plants require to survive winter. More studies at global 
and regional scales are needed to assess the potential impact of climate warming on plant adaptation to winter (Breton et al., 2000; Tomashow, 1999; Horvath et al., 2003; Chinnusamy et al., 2006).

The goal of this review is to discuss the metabolic strategies woody plants use to survive these stresses caused by LT and the primary mechanisms that plants use to control freezing dynamics and reduce freezing injury in living tissues, as well as the physiological and molecular transformations that take place along winter metabolism.

\section{PLANT ADAPTATION TO WINTER LOW TEMPERATURES}

Winter survival is a complex phenomenon that does not solely rely on the plant ability to withstand the direct effects of extreme LT. During long overwintering periods, plants are exposed to multiple abiotic (ice encasement, frost heave, desiccation, anoxia) and biotic (snow mould and other psychrophylic pathogens) stresses. An interesting example on the way both factors interact is found in asymptomatic grapevines (Vitis vinifera L.) systemically infected with Agrobacterium vitis; once a freezing episode occurs, trunks split because of the freezing injury and, only then, galls caused by this bacterium develop, eventually girdling trunks and killing the whole vine (Burr and Otten, 1999). Tolerance to these stresses is partly based on shared adaptive traits and, consequently, cross-adaptation to environmental stresses is a key aspect of plant adaptation to cold (Tomashow, 1999; Breton et al., 2000).

\section{Plant diversity in tolerance to low temperature}

Within the plant kingdom there is a wide range of diversity in LT tolerance, from low levels of hardiness (0 to $-5{ }^{\circ} \mathrm{C}$ ) in herbaceous species such as potatoes (Solanum tuberosum L.), to intermediate levels of hardiness ( -5 to $10{ }^{\circ} \mathrm{C}$ ) in winter annuals such as wheat (Triticum vulgare L.) and rye (Secale cereale L.), to high levels of hardiness $\left(-10\right.$ to $\left.-20{ }^{\circ} \mathrm{C}\right)$ in winter annuals and perennials such as winter cereals, grasses and trees, to extremely hardy deciduous trees and shrubs such as black locust (Robinia pseudoacacia), red osier dogwood (Cornus sericea) and aspen (Populus tremuolides), whose cells may survive to temperatures as low as $-196{ }^{\circ} \mathrm{C}$ (Guy, 1990; Gusta et al., 2005; Larcher, 2005).

A differential thermal analysis is used for recording heat release when water freezing occurs in a tissue sample. A high temperature exotherm is produced when extracellular water is frozen, which occurs at temperatures close to $0{ }^{\circ} \mathrm{C}$, being considered "high" for cold hardiness standards. A LT exotherm, occurring at variable temperatures and depending on species, is produced when the tissue is irreversible damaged, and thus will die; this usually happens at temperatures well below the freezing point. The hardy species mentioned above do not frequently exhibit such LT exotherm, thus implying that they can thrive in very harsh environments (Burke et al., 1974). Figure 1 presents data from a demonstration experiment in our lab, showing the freezing exotherm of 'Red Delicious' apple (Malus domestica L.) flower buds at the "first-pink" phenostage run in a scanning calorimeter. Data from two overlapping populations can be easily distinguished along the exotherm line, suggesting the existence of two flower structures freezing almost simultaneously.

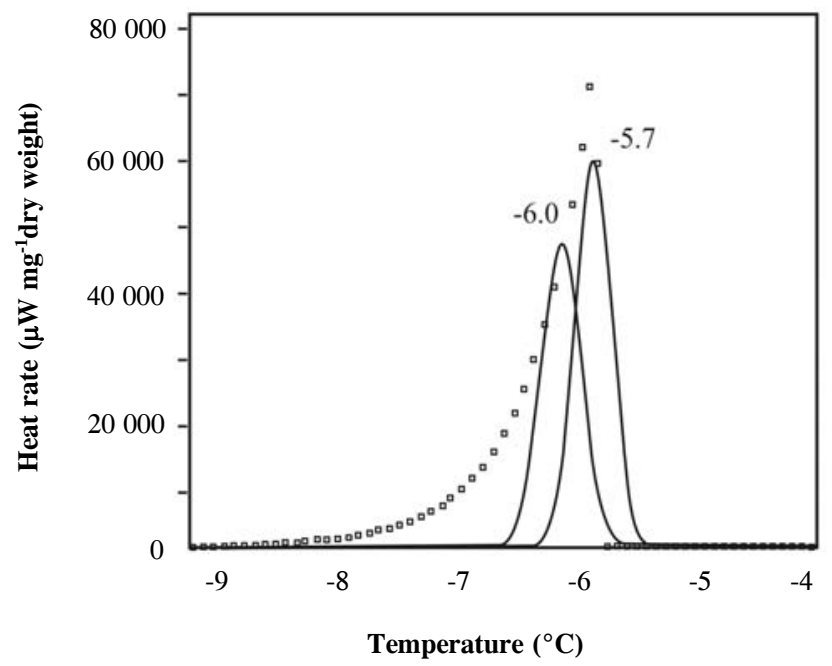

Figure 1. Freezing exotherm under a controlled test by differential scanning calorimetry of an apple flower bud at the first pink phenophase. Areas under curves are the energy liberated as heat is released by water molecules during freezing. The main signal is separated by second derivative analysis into two water molecule populations, suggesting different compartments freezing almost simultaneously.

Within a given species the range in hardiness can be substantial, and within a plant there is also a wide range in cold hardiness among different tissues and organs. For example, roots are less tolerant to subzero temperatures than shoots; flower buds are more sensitive than vegetative buds. In general, most temperate plants acquire chilling and freezing tolerance upon exposure to cold stress, although many agronomical important crops are incapable of cold acclimation (Breton et al., 2000; Larcher, 2005).

\section{Strategies to resist low temperatures}

The mechanisms that allow plants to withstand subfreezing temperatures are classified into two main categories: (1) avoidance of freezing through supercooling and 
(2) tolerance of freezing by extracellular ice formation. Both survival strategies are present in woody plants (Levitt, 1980; Tomashow, 1999).

1) Freezing avoidance. Tissues display deep supercooling, implying that some of the cellular water remains liquid well below the freezing point. As early as 1974, the theoretical limit of supercooling was set at $-38.1^{\circ} \mathrm{C}$ for pure water droplets in emulsion (Burke et al., 1974). In the plant cell deep supercooling is enabled by an effective isolation of the protoplast from the nucleating effect of extracellular ice. In general, freezing avoidance occurs in some tissues and organs of woody trees: xylem ray cells of many hardwoods, flower buds of angiosperms and both shoot and floral primordia of conifers. A particular mention should be done to the cold hardy azalea (Azalea spp.), in which a phenolic-rich barrier isolates flower buds from stems and prevents ice crystals from xylem to grow towards the buds. When such barrier was disrupted, either by mechanical means or sublethal heat stress, the supercooling capacity disappeared since no hydrophobic obstacle was met by ice crystals (Chalker-Scott, 1992).

2) Freezing tolerance. This mechanism involves water migration into intercellular spaces and a gradual growth of extracellular ice. At slow cooling rates, cold acclimated tissues undergo equilibrium freezing; $i$. $e$., diffusion of cellular water is rapid enough to maintain the chemical equilibrium between the protoplasm and the ice. In contrast, a rapid cooling may result in chemical disequilibrium and induction of intracellular freezing. Tolerance of extracellular freezing and the ensuing dehydration stress is the major survival mechanism of woody plants (Breton et al., 2000; Puhakainen, 2004b).

According to Tomashow (1999) and Welling and Palva (2006) a third mechanism can be found in herbaceous plants. These plants may cold acclimate very rapidly in response to nonfreezing-LT by short transient periods in their growing season; this adaptation has been extensively studied in Arabidopsis and the molecular mechanisms involved are well characterized. However, this class of cold acclimation is limited just to 5 to $8{ }^{\circ} \mathrm{C}$ for a few days. In winter they must survive through a different strategy of avoidance: they die, leaving behind a protected seed, bulb or tuber source. While this strategy is used by herbaceous, the long-living woody species which retain their above-ground biomass, require the strategies described above to persist the winter months.

Elucidated molecular mechanisms of cold acclimation, indicate that herbaceous and woody plants could share some mechanisms. Both the signal process and the cold- regulated target genes appear to be shared (Welling and Palva, 2006).

\section{Adaptive mechanisms to low temperature during winter}

Woody plants of the temperate zone are exposed to LT each winter. Their ability to survive is based on adaptive mechanisms by which plants enter a state of dormancy and to become cold hardy. In this manner, they develop freezing tolerance during cold episode periods, reaching a LT tolerance at levels otherwise lethal to unhardened plants. The degree of hardening varies in relation to the plant growth stage and is closely associated with the winter dormant period. Because winter dormancy and cold hardiness are overlapping events in plants, the processes involved are difficult to distinguish and separate. Nevertheless these mechanisms include a complex dynamic process that controls not only the development of rest and freezing tolerance, but secures their accurate initiation and termination. This process includes a temporary suspension of visible growth of any plant structure with a meristem, the down-regulation of photosynthesis and respiration, the partial or total loss of aerial organs, the formation of specialized organs such as buds, and the buildup of cryoprotective substances. These active physiological changes in trees are also important to complete the freeze tolerance process, which allow survival at the very LT encountered in high latitudes and elevated sites (Kontunen-Soppela et al., 2002; Puhakainen et al., 2004b). An hypothetical example based in our own experience is presented in Figure 2a, showing the typical weather conditions in a apple growing area located at 2000 masl in northern México; Figure $2 \mathrm{~b}$ shows that during endodormancy the respiration rate in root tips is faster than in buds, a behavior that is reversed during ecodormancy.

Before getting into a description of dormancy and cold hardiness, it is important to be aware that there has been frequent conflicting reports about them. For example, Faust et al. (1991) using magnetic resonance imaging hypothesized that apple bud endodormancy is characterized by the bound conditions of its water molecules, although this is highly unlikely since under such conditions cells would become dehydrated. Previously, however, Vertucci (1990) demonstrated in dormant pea (Pisum sativum L.) seeds that the bound water fraction is formed by two populations, one being transient; and in any case this physical evidence is more related to cold hardiness than to dormancy itself. Figure 3 (Gardea, 1992; Pers. communication $^{1}$ ) shows a dramatic change in bound water in

\footnotetext{
${ }^{1}$ Alfonso A. Gardea (1992) Water partitioning and respiration activity of dormant grape buds. PhD thesis. Oregon State University. $121 \mathrm{p}$.
} 
overwintering grapevine buds, according to the definition by Burke et al. (1974) that "bound water is that one remaining liquid at temperatures as low as $-30{ }^{\circ} \mathrm{C} \cdot{ }^{*}$. Although no morphological differences may be distinguished on buds, their cold hardiness changed dramatically between sampling dates.

Dormancy. Perennial plants of the temperate zones have developed unique mechanisms to anticipate the regular environmental changes that occur along the seasons progression. At the end of the growing season they cease development and assume a dormant and freezing-tolerant state, even when temperatures still favor growth, a strategy that protects against a sudden arrival of winter. Later in winter they may already anticipate spring by breaking dormancy while freezing tolerance remains high. This synchrony between of growth and seasons - referred to as 'dormancy cycling' - has received considerable attention, but many of the underlying mechanisms have remained unsolved for buds, as well as for seeds (Rinne et al., 2001; Horvath et al., 2003).

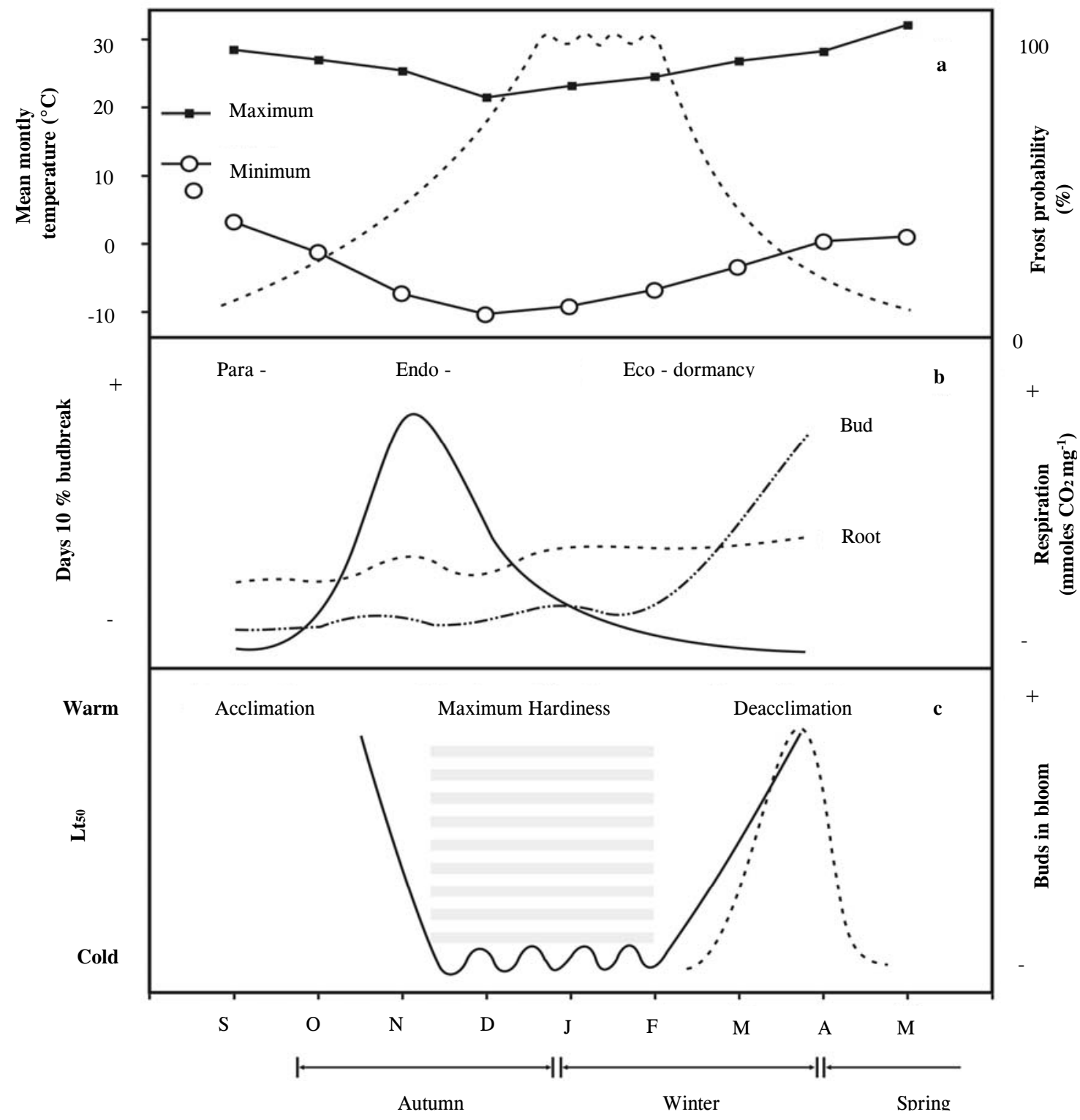

Figure 2. Descriptive development proposed for some aspects of winter metabolism of deciduous fruit species. a) Temperature conditions showing monthly maximum and minimum averages and frost probabilities. b) Dormancy phases (para-, endo- and ecodormancy) as defined by the time required to budbreak by field growing plants transferred to growing conditions at fixed intervals along the dormant period. Dotted lines show buds and roots respiration patterns. c) Cold hardiness as expressed by the low temperature required to kill $50 \%$ of the buds, showing the acclimation, maximum hardiness and deacclimation periods. Dotted lines show an approximate common bloom period for many genotypes in the northern hemisphere. 
A

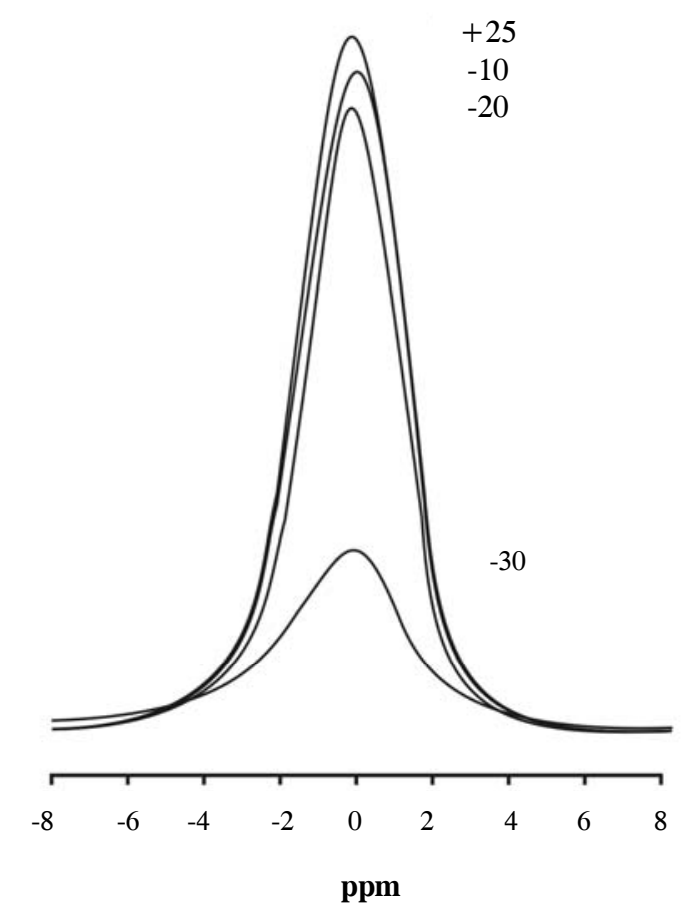

B

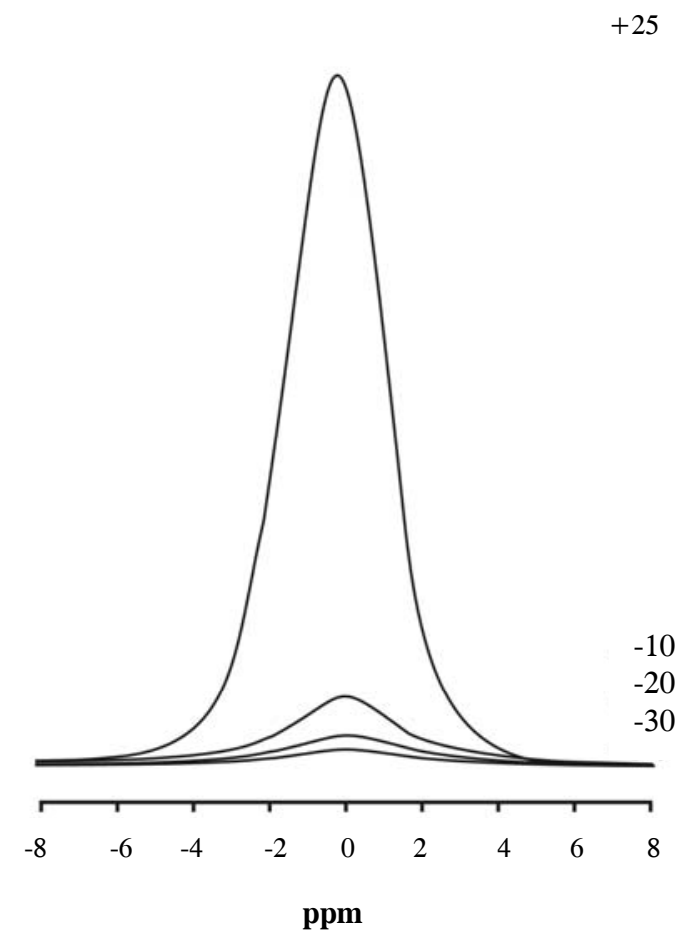

Figure 3. H-NMR spectra of 'Pinot Noir' winegrape primary buds sampled on A) January, when fully hardy; and B) on April once deacclimation ended. Area under a curve represents water remaining liquid at the labeled temperatures; thus, liquid water at $-30{ }^{\circ} \mathrm{C}$ represents the bound fraction (A. Gardea, 1992; Pers. Communication; Opus cited).

In boreal tree species the acquisition of dormancy, triggered by the reduction in daylength, is a prerequisite for cold hardening. In order to cease growth and acquire dormancy in a timely fashion, perennials often sense photoperiod changes by means of phytochromes (Weiser, 1970). Phytochromes shuttle between the cytoplasm and the nucleoplasm and generate a putative signal (or set of signals) that is sent out from the leaves, via petioles and stems, towards the shoot apex. The shoot apex, as the actual target of the signal, ceases its morphogenic activity and responds by transforming itself into a dormant bud, which is also freezing-tolerant (Weiser, 1970). Subsequently, the dormant bud recovers the potential for further growth and development, only after it has received adequate chilling exposure (Fuchigami and Nee, 1987).

More recent studies have identified conditions under which bud growth is inhibited by signals generated inside the vegetative bud or as the direct response to unfavorable conditions for growth. Lang et al. (1987) categorized these seemingly separate growth-inhibited or dormant states as: (1) paradormancy, the inhibition of growth by distal organs; (2) endodormancy, the inhibition of growth by internal bud signals; and (3) ecodormancy, the inhibition of growth by temporary unfavorable environmental conditions. Although these types of dormancy are usually thought of as occurring separately, any individual bud might be simultaneously controlled by any or all of the signals regulating these aspects of dormancy (Yamaguchi et al., 1999; Rinne et al., 2001; Wisniewski et al., 2004; Ramos et al., 2005). A descriptive proposal is shown in Figure $2 b$.

1) Paradormancy is the best studied of the three types of dormancy, and is sometimes referred to as apical dominance or correlative inhibition. This process allows plants to devote resources to reproduction and plant architecture control; also for maximizing light harvesting, while allowing for regeneration when individual shoots become damaged. Plants undergo adaptive changes as early as the middle of summer. The shoot apices cease active growth and become enclosed in protective bud scales to form dormant buds. Leaf and flower bud meristems become also differentiated as late as the end of summer. Following terminal bud formation, generally there is a period in which axillary buds can be forced to grow by removing the terminal bud that exerts apical dominance; even whole-tree defoliation will stimulate bud growth (Muthalif and Rowland, 1994; Levi et al., 1999; Horvath et al., 2003). If field growing plants are defoliated, their apical buds removed and transferred to conditions conductive to grow, axillary buds will break; the 
required period for growth induction will increase as buds get into an endodormant state.

2) Endodormancy is an important mechanism for protecting buds by ensuring that meristems will not resume growth until the return of stable permissive conditions. This is caused by plant endogenous factors, which once established, no growth can be achieved until a particular chilling requirement (CR) has been satisfied. In order for budbreak to occur, plants must be exposed to LT for a cumulative time. By mid to late autumn, as days become increasingly shorter and night temperatures decrease, inhibitory control of bud growth shifts to reside within the bud itself so that plants are incapable of emerging from this status by removal of terminal buds or by defoliation. Resumption of growth and budbreak require sufficient exposure to LT. This CR is determined genetically and can be calculated rather differently depending on the model used; one example is the number of hours between 0 and $7{ }^{\circ} \mathrm{C}$ necessary for $>50 \%$ budbreak upon exposure to higher temperatures. CR can range widely depending on species and genotype (Muthalif and Rowland, 1994; Horvath et al., 2003).

3) Ecodormancy. Once the CR is satisfied, growth may remain arrested by adverse environments, but it can be resumed when conditions become favorable (Fuchigami and Nee, 1987; Levi et al., 1999). Buds are capable of resuming growth upon exposure for two to three weeks at temperatures near $20^{\circ} \mathrm{C}$ (Muthalif and Rowland, 1994; Rinne et al., 2001). Physiological time scales have been developed to quantify such heat requirements and expressed as degree days, heat units and others.

Cold hardiness. When getting familiar with cold hardiness, it is a must to begin with a pioneer report by Weiser (1970). It provides a quick start to comprehend what was done, as well as a starting point when planning further research. Cold hardiness is the ability of plants to survive subfreezing temperatures; it is also the seasonal transition of plant hardiness from a tender to a hardy condition. Temperature contributes to the degree of hardiness in an indirect manner through its effects on the cycle of annual development (Thomashow, 1999; Welling and Palva, 2006).

The cold hardiness of plants changes seasonally, since the annual cycle of hardening and dehardening is closely synchronized to the progression of winter temperatures (see Figure 2c). Cold hardening or acclimation (1) is a gradual process; in northern conifers is first triggered by a shortening photoperiod and its progression parallels the decreasing temperatures. In the second stage of hardening plants achieve its deepest hardiness (2). Finally the third stage known as deacclimation (3) occurs in late winter and early spring; hardiness is progressively lost due to increasing temperatures (Kontunen-Soppela et al., 2002; Welling and Palva, 2006).

1) Acclimation. In woody plants the cold acclimation process consists of two stages. The first stage is triggered by a short photoperiod and changes in light spectrum, while the second is induced by LT (Weiser, 1970; Li et al., 2002). Photoperiod has a central role as the primary signal to induce growth cessation and dormancy development as mentioned before, but also to initiate cold acclimation. Subsequent LT exposure is the main factor required to increase freezing tolerance. Freezing tolerance development in deciduous trees is rather a slow process, but ultimately results in a very high tolerance, down to $196{ }^{\circ} \mathrm{C}$ in buds and stems of boreal species (Rinne et al., 2001; Li et al., 2002). Sometimes this rule does not apply; such is the case when becoming dormant is not compulsory for developing cold acclimation, and both processes develop independently and without apparent synchrony. For example, some species growing at the high elevation timberlines in subtropical latitudes behave as perennials, while withstanding freezing temperatures almost year round. However, in most species growth cessation is regarded as a prerequisite for cold acclimation (Junttila and Kaurin, 1990).

2) Maximum hardiness. By the coldest days of winter, plants have attained their maximum level of adaptation to a cold environment, although small variations are associated with weather conditions prevailing in the previous day. A sunny day with warm, even hot, temperatures will result in a loss of hardiness the following day, and such changes are reversible (Weiser, 1970).

3) Deacclimation. Occurs in late winter and early spring, when hardiness is progressively reduced due to increasing temperatures, although specific stages in dehardening have not been completely studied. The same as the annual development of dormancy and cold hardening occur simultaneously in the fall, the release from dormancy and deacclimation in the spring is also simultaneous (Kontunen-Soppela et al., 2002; Gusta et al., 2005; Welling and Palva, 2006). In fact, cell metabolic activity may increase before the plant frost hardiness is lost (Nasholm and Ericsson, 1990). The timing of cold hardening, as well as the onset and release of dormancy, is genetically determined although they are affected also by the current weather. In the case of trees with a wide distribution range, the timing of bud set and the development of frost resistance can vary significantly between different provenances or ecotypes of the same species (Repo et al., 2000; Kontunen-Soppela et al., 2002). 
Blooming of deciduous fruit trees may coincide when last freeze occurs, so the risk of loosing the crop is always an issue. Ice nucleation on flowers may be triggered by ice-nucleation bacteria, since these microorganisms need to induce a mechanical injury as a means to invade the tissue; therefore, they have evolved a specific protein in their cell coat to act as a nucleating site (Lindow, 1995). Figure 4 illustrates the protein nature of the icenucleator present in the cell coat of Pseudomonas syringae pv. syringae. While viable bacteria nucleate ice at warm subfreezing temperatures $\left(\mathrm{ca} .-2.1{ }^{\circ} \mathrm{C}\right)$, cells exposed to chloroform fumes are no longer viable and proteins slowly denature, loosing their nucleating properties over time $\left(-3.7^{\circ} \mathrm{C}\right)$; in comparison, autoclaving denatures proteins quickly and this characteristic is lost (Gardea $e t$ al., 1992).

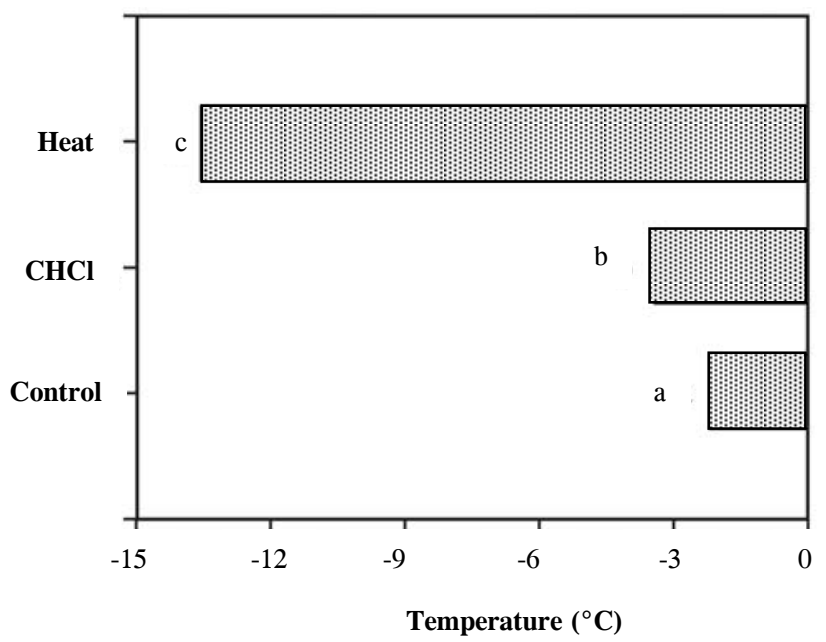

Figure 4. Nucleation temperatures of Pseudomonas syringae pv syringae strain B-15 suspensions. Aliquots were adjusted to the same optic density before autoclaving and after exposure to chloroform fumes. Adapted from Gardea et al. (1992).

In deciduous woody plants, many genes and proteins related to cold acclimation may also be connected to the plant dormancy status. Although the function of most cold-induced proteins is not known yet (Kontunen-Soppela et al., 2002; Horvath et al., 2003; Wisniewski et al., 2004; Welling and Palva, 2006).

\section{Biochemical changes along winter metabolism}

Winter metabolism is associated with biochemical alterations in plants. The best characterized changes include alterations in gene expression, changes in hormone levels, increase in soluble sugars, accumulation of osmoprotectants and cryoprotective proteins, as well as modification of membrane lipid composition. The causal relationship of these changes to increased cold tolerance is still unclear, but several genes and regulons involved are being unraveled (Chinnusamy et al., 2006; Welling and Palva, 2006).

The LT adaptation process results in numerous biochemical changes within the cell. As early as 1970, Weiser proposed that acclimation requires transcriptional activation of a set of genes normally not expressed under non-acclimating conditions. Since cold tolerance is inducible, it has been found that this induction involves the synthesis of novel peptides, which by means of their enzymatic activity or their structural properties confer this tolerance to tissues (Guy, 1990; Thomashow, 1999; Chinnusamy et al., 2006). The content of growth regulators changes, ABA (abscisic acid) increases while gibberellins decrease. Growth promotion by gibberellins is negatively associated with freezing tolerance, whereas a positive association is found by ABA-induced dormancy (Heino et al., 1990). An increase in ABA triggers gene expression for stress proteins synthesis. ABA and dehydrins play an essential role in the photoperiodic induction of winter dormancy and the acquisition of frost tolerance in the acclimation stage (Larcher, 2005). There is a close correlation between soluble protein content and cold tolerance, associated with an increase in the amount of mRNA required for protein synthesis, such as cold-regulated proteins "COR proteins" (Thomashow, 1999; Puhakainen et $a l .$, 2004a).

Plasma membrane is thought to be the primary site of injury during freezing; thus, most alterations are aimed at preserving membranes integrity (Thomashow, 1999). Plant membranes undergo both qualitative and quantitative modifications through cold acclimation. The lipid composition of the plasma membrane and chloroplast envelopes change in a way that the threshold temperature of membrane damage is lowered compared to nonacclimated plants. This is due to the increasing fluidity of membranes, resulting from a change in lipid composition towards an increase in desaturated fatty acids (KontunenSoppela et al., 2002; Martz et al., 2006a).

Carbohydrate content varies according to the hardening status of a tissue. Starch concentrations decrease and the concentrations of soluble sugars increase in cold hardening tissues of woody plants (Greer et al., 2000; Dhanaraj et al. 2004). The oligosaccharides raffinose and stachyose are especially associated with cold hardiness, LT and dormancy, but sucrose also enhances cold hardiness and desiccation tolerance of buds in woody plants. In addition to carbohydrates, woody plants accumulate other solutes when exposed to LT, such as proline or glutamic acid. In general, the function of solutes is to maintain turgor in dehydrating cells, but they may also have 
cryprotective effects on macromolecules (KontunenSoppela et al., 2002; Wang et al., 2003).

Cold temperatures also lead to oxidative stress in plants by inducing reactive oxygen species. Therefore, the activity of antioxidant enzymes (ascorbate peroxidases, glutathione reductase, superoxide dismutase and others) taking part in the scavenging of free radicals, as well as the levels of antioxidant compounds, is induced by LT and plays an important role in recovery from freezeinduced damage (Siller et al., 1992; Kontunen-Soppela et al., 2002; Renaut et al., 2006).

\section{Regulatory genes that control the overall mechanism of LT responses}

Ability for cold acclimation is a quantitative trait expressed in LT-induced transcriptional reprogramming and leads to several biochemical and physiological alterations in the plant. The complex plant response to LT, which involves many genes (Table 1) and biochemical-molecular mechanisms, is schematically represented in Figure 5. The ongoing elucidation of the molecular control mechanisms of cold stress tolerance, which may result in the use of molecular tools for engineering more tolerant plants, is based on the expression of specific cold-regulated genes (COR genes). These COR genes induced by cold can be classified into tree main categories: (i) Genes encoding enzymes or structural components believed to participate in direct protection of cells against freezing damage. (ii) Genes encoding transcription factors and other regulatory proteins controlling the LT responses either transcriptionally or posttranscriptionally. (iii) Genes involved in signaling cascades of LT (Thomashow, 1999; Puhakainen et al., 2004b; Chinnusamy et al., 2006).

i) Genes encoding enzymes or structural components to protect against freezing damage. To cope with cold stress, plants activate a large set of genes leading to the accumulation of specific cold-associated proteins. This group includes genes encoding late embryogenesisabundant proteins (LEA), heat-shock proteins (Hsps), enzymes required for osmolyte biosynthesis, antifreeze and detoxification proteins. LEA and Hsps proteins are two major types of stress-induced proteins that accumulate upon water, salinity, and extreme temperature stress. They have been shown to play a role in cellular protection during the stress (Close, 1997; Thomashow, 1999; Wang et al., 2003; Renaut et al., 2006).

LEA have been found in a wide range of plant species in response to water deficit resulting from desiccation, cold and osmotic stress. Predictions of secondary struc- tures suggest that most LEA exist as random -coiled helices. Characteristics of these proteins are: (1) Hydrophilicity, together with other osmotic stress-induced protein are grouped into a class termed hydrophilins, because of their high hydrophilicity index $(>1.0)$ and glycine content $(>6$ $\%)$; (2) Heat stability, since they do not coagulate upon boiling; and (3) In most cases, their related gene expression is transcriptionally regulated and responsive to ABA. The functions of LEA are not completely known, but their considerable induction by cold stress and their structural characteristics allows the prediction of some of their functions. It has been suggested that they act as water-binding molecules, in ion sequestration and in macromolecule and membrane stabilization, $i$. $e$. chaperone-like activity (Close 1997; Puhakainen et al. 2004b).

LEA-group II or dehydrin (DHN) is the most conspicuous of soluble proteins induced by dehydrative stress. A literature survey revealed that they have been detected in well over 100 independent studies of drought, cold and salinity stresses. Several lines of evidence are consistent with a role of DHN's in membrane interactions including immunolocalization, plasma membrane association and adoption of an $\alpha$-helix structure by several cereal DHN's in the presence of sodium dodecyl sulfate. It also shows that DHN's may protect enzymes from freezing damage in vitro. The WCS120, a wheat DHN at 0.2 $\mu \mathrm{M}$ has the same efficiency as $250 \mathrm{mM}$ sucrose in in vitro cryoprotection assays of lactate dehydrogenase, meaning that WCS120 is over a million-fold more efficient than sucrose on a molar basis. Similar results have been obtained with other DHN's (Breton et al., 2000).

Compatible solutes or osmolytes are accumulated in response to osmotic stress. The function of compatible solutes is to maintain cell turgor and, thus, the driving gradient for water uptake. They can also act as freeradical scavengers or chaperones by stabilizing membranes and proteins. Osmolytes fall into three major groups: amino acids $(e . g .$, proline $)$, quaternary amines (e. g., glycine betaine) and polyol/sugars (e. g., mannitol). Overexpression of osmolytes in transgenic plants can result in improved stress tolerance (McNeil et al., 1999; Diamant et al., 2001), but information related to woody plants is limited. The osmotic adjustment of dehydrated cells is not completely explained by the accumulation of osmolites during hardening. There are evidences that LEA also participate in membranes stabilization against freeze-induced injury. Solutes and polypeptides could stabilize membranes either by direct interaction with membrane surfaces or, indirectly, by their strong interaction with water (Close, 1997; Wang et al., 2003). 


\section{Signals: Low Temperature/Light changes}
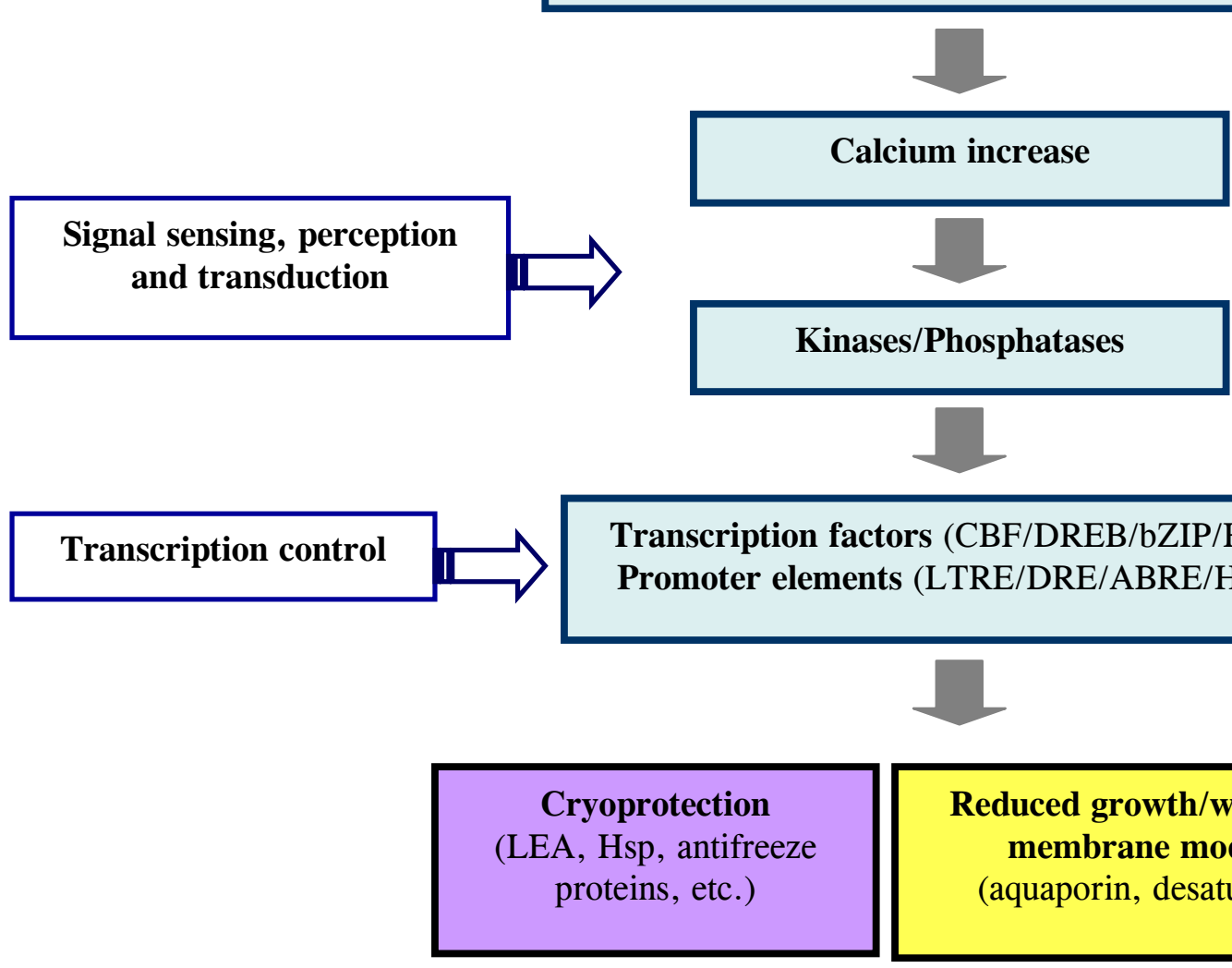

\section{Reduced growth/water content/ membrane modification (aquaporin, desaturases, etc.)}

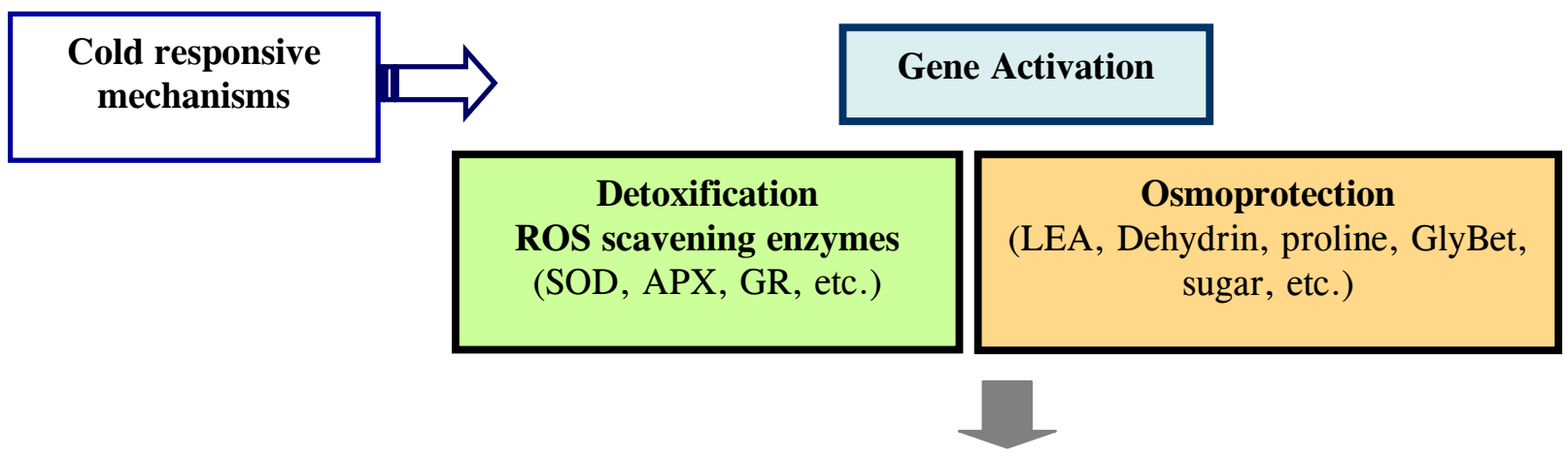

Freezing Tolerance

Figure 5. Diagram showing regulation of cold responsive genes in woody plants. Signals are first perceived by putative membrane associated receptor(s) and then transmitted to the nucleus. Expression is regulated by both ABA-independent and ABA-dependent pathway. Calcium, CDPKs and MAPKs are intermediates of the signal sensing, perception and transduction process. The transcription factors activate the promoters of coldregulated genes. This triggers the cold responsive mechanisms (gene activation). The transcribed mRNAs are translated to different proteins that contribute to the development of freezing tolerance (Breton et al., 2000; Wang et al., 2003).

Abbreviations: ABA, abscisic acid; ABRE, ABA responsive elements; APX, ascorbate peroxidase; bZIP, basic-leucine zipper transcription factor; CBF, C repeat binding factors; CDPKs, calcium depended protein kinases; COR genes, cold regulated genes; DRE, dehydration responsive element; DREB, dehydration responsive biding factors; GR, glutathione reductase; HSE, heat shock promoter element; HSF, heat shock transcription factor; Hsp: heat shock protein; LEA protein: late embryogenesis abundant protein; LTRE, low temperature responsive element; MAPKs, mitogen activated protein kinases; SOD, superoxide dismutase. 
Table 1. Genes involved in winter metabolism of deciduous woody plants.

\begin{tabular}{|c|c|c|c|}
\hline Functional category & Gene/protein ${ }^{+}$ & Species & Reference \\
\hline $\begin{array}{l}\text { Transcriptional } \\
\text { control }\end{array}$ & $\begin{array}{l}P c C B F 1 \\
C B F \\
P t C B F 1-4 \\
B p C B F\end{array}$ & $\begin{array}{l}\text { Cherry (Prunus cerasus) } \\
\text { Cherry (Prunus avium) } \\
\text { Poplar (Populus sp.) } \\
\text { Birch (Betula pendula) }\end{array}$ & $\begin{array}{l}\text { Owens } \text { et al., } 2002 \\
\text { Kitashiba } \text { et al., } 2004 \\
\text { Welling \& Palva, } 2006 \\
\text { Puhakainen } \text { et al., 2004b }\end{array}$ \\
\hline Signal & PtABI3 & Poplar (Populus trichocarpa) & Rohde et al., 2002 \\
\hline Membrane modification & $\begin{array}{l}\text { BpFAD, BpKASII. } \\
\mathrm{H}+\mathrm{ATPase} \\
\mathrm{H}+\mathrm{ATPase} \\
\mathrm{H}+\mathrm{ATPase} \\
\text { Lipoprotein }\end{array}$ & $\begin{array}{l}\text { Birch (Betula pendula) } \\
\text { Peach (Prunus persica) } \\
\text { Apple (Malus domestica) } \\
\text { Pine (Pinus resinosa) } \\
\text { Stone fruits (Prunus } s p .)\end{array}$ & $\begin{array}{l}\text { Martz et al., 2006a } \\
\text { Gevaudant } \text { et al., } 2001 \\
\text { Mattheis \& Ketchie, } 1990 \\
\text { Martz et al., 2006b } \\
\text { Renaut } \text { et al., } 2006\end{array}$ \\
\hline $\begin{array}{l}\text { Carbohydrate metabolism (syn- } \\
\text { thesis of osmoprotectants such as } \\
\text { sucrose, fructose, etc) }\end{array}$ & $\begin{array}{l}\text { Beta amylase } \\
\text { GAPDH, sucrose synthase, aldose } \\
\text { reductase. } \\
\text { Rubisco }\end{array}$ & $\begin{array}{l}\text { Blueberry (Vaccinium corymbosum) } \\
\text { Poplar (Populus sp.), pine (Pinus sp). } \\
\text { Poplar (Populus sp.) }\end{array}$ & $\begin{array}{l}\text { Dhanaraj et al.,2004 } \\
\text { Ferullo \&Griffith, } 2001\end{array}$ \\
\hline Detoxification/ Antioxidants & $\begin{array}{l}\text { GR-1H } \\
\text { APX }\end{array}$ & $\begin{array}{l}\text { Red spruce (Picea rubens) } \\
\text { Poplar (Populus sp.) }\end{array}$ & $\begin{array}{l}\text { Renaut et al., } 2006 \\
\text { Hausladen \& Alscher, } 1994 \\
\text { Renaut et al., } 2006\end{array}$ \\
\hline Cell cycle & $\begin{array}{l}\text { PttCDKA, PttCDKB } \\
\text { Beta-Tubulin } \\
(55 \mathrm{kDa})^{+++}\end{array}$ & $\begin{array}{l}\text { Poplar hybrids ( } P \text {. tremula } x \text { P. } \\
\text { tremuloides) } \\
\text { Maple (Acer platanoides), apple } \\
\text { (Malus domestica, 'M9'), oak (Quer- } \\
\text { cus robur), pine (Pinus sylvetris). }\end{array}$ & $\begin{array}{l}\text { Espinosa-Ruiz et al., } 2004 \\
\text { Bergervoet } \text { et al., } 1999\end{array}$ \\
\hline $\begin{array}{l}\text { Stabilization of membranes and } \\
\text { proteins: LEAs (Dehydrin) }\end{array}$ & $\begin{array}{l}\text { LEAIII (WAP27) } \\
\text { ppdhn1, ppdhn2 } \\
\text { Dhn }(60,14 \mathrm{kDa}) \\
\text { Dhn }(\text { Pa rab21) } \\
\text { Dhns }(\text { ROD60, 44, 48)/ } 24 \mathrm{kDa} \\
\text { dhn. } \\
\text { BpuDhn1,BpuDhn2 } \\
\text { Dhn (Bplti36) } \\
\text { PV-dhn } \\
\text { mddhn }\end{array}$ & $\begin{array}{l}\text { Mulberry (Morys bombycis) } \\
\text { Peach (Prunus persica) } \\
\text { Blueberry (Vaccinium corymbosum) } \\
\text { Almond (Prunus amygdalus) } \\
\text { Red-osier dogwood (Cornus sericea) } \\
\text { Birch (Betula pubescens) } \\
\text { Birch (Betula pendula) } \\
\text { Pistachio (Pistacia vera) } \\
\text { Apple (Malus domestica) }\end{array}$ & $\begin{array}{l}\text { Ukaji et al., } 2001 \\
\text { Wisniewski } \text { et al., } 2006 \\
\text { Dhanaraj } \text { et al., } 2005 \\
\text { Campalans et al., } 2000 \\
\text { Welling \& Palva, } 2006 \\
\text { Welling et al., } 2004 \\
\text { Puhakainen } \text { et al., } 2004 \mathrm{~b} \\
\text { Yakubov } \text { et al., } 2005 \\
\text { Garcia-Bañuelos } \text { et al., } 2007\end{array}$ \\
\hline HSP & $\begin{array}{l}\text { HSP (WAP20) } \\
\text { HSP (CsHSP17.5) } \\
\text { HSP } \\
\text { HSP22 and HSP70 } \\
\text { HSP70 }\end{array}$ & $\begin{array}{l}\text { Mulberry (Morus bombycis) } \\
\text { Chestnut (Castanea sativa) } \\
\text { Poplar (Populus tremula) } \\
\text { Poplar (Populus hybrid) } \\
\text { Stone fruits (Prunus sp.) }\end{array}$ & $\begin{array}{l}\text { Ukaji et al., } 1999 \\
\text { Lopez-Matas et al., } 2004 \\
\text { Wang } \text { et al., } 2003 \\
\text { Renaut } \text { et al., } 2006 \\
\text { Renaut } \text { et al., } 2006\end{array}$ \\
\hline $\begin{array}{l}\text { Antifreeze protein. Cryo- } \\
\text { protective activity }\end{array}$ & $\begin{array}{l}\text { PR-10 (Pin } m \text { III) } \\
\text { PmPR10 } \\
\text { PR-10 (WAP18) }\end{array}$ & $\begin{array}{l}\text { White pine (Pinus monticol) } \\
\text { White pine (Pinus monticol) } \\
\text { Mulberry (Morus bombycis) }\end{array}$ & $\begin{array}{l}\text { Yu et al., } 2000 \\
\text { Liu et al., } 2003 \\
\text { Ukaji et al., } 2004\end{array}$ \\
\hline
\end{tabular}

${ }^{+}$Genes/proteins up-regulated during winter metabolism. ${ }^{++}$Correlation between sugar content and cold hardiness reported in many woody species. ${ }^{+++}$ Down-regulated protein. Abbreviations. ABA, abscisic acid; ABI, ABA-insensitive; APX, ascorbate peroxidase; CBF, c-repeat-binding factor; CDK, cyclin-dependent kinases; Dhn, dehydrin; FAD, fatty acid desaturase; GAPDH, glyceraldehyde-3-phosphate dehydrogenase; GR-1H, glutathione reductase-1 hardened; HSP, heat-shock protein; KASII, 3-ketoacyl-ACP synthase II; lti low, but non freezing, temperature induced genes, P5CS, pyrroline-5carboxylate synthetase; PR-10, pathogenesis-related protein; rab, responsive to ABA; ROD, Red-osier dogwood; WAP, winter accumulating proteins.

ii) Genes encoding transcription factors and regulatory proteins. The LT-induced expression of coldresponsive genes is mediated by distinct signal transduction pathways. One of the most intensively studied coldresponse pathways is the C-repeat-binding factor (CBF) pathway, which is established as an integral component of the cold-acclimation response (Thomashow, 1999; $\mathrm{Pu}-$ hakainen et al., 2004a,b). Central players in the CBF pathway are the transcriptional activators, named CBF1/DREB1b, CBF2/DREB1c and CBF3/DREB1a, that bind to the C-repeat (CRT)/dehydration responsive element (DRE)/LT-responsive element (LTRE) elements present in the promoters of several cold- and droughtinducible genes. The CBF/DREB1 genes themselves are transiently induced by cold stress, and this induction precedes that of the downstream target genes with the CRT/DRE/LTRE cis-elements (Liu et al., 1998; Thomashow, 1999; Chinnusamy et al., 2006). Components of the CBF pathway have been identified from several other plant species, and the pathway seems to be 
conserved in flowering plants. Unfortunately, information currently available about the function or components of the CBF pathway in woody plants is more limited (Jaglo et al., 2001; Puhakainen et al., 2004b; Welling and Palva, 2006).

iii) Genes involved in signaling cascades (LT perception signal). Cold is first sensed by either the plasma membrane or cytoplasmic and chloroplastic molecular complexes, transducing the signal via a cascade of kinases and phosphatases, leading to the activation of specific transcription factors, which in turn activate the transcription of the plethora of COR genes. This differential gene expression is responsible for both, the metabolic adjustment of growth at LT and the development of freezing tolerance. Understanding the regulation of these molecular events is the goal of many studies (Breton et al., 2000; Puhakainen et al., 2004b; Chinnusamy et al., 2006). LT signal transduction starts with the perception of the cold signal by a yet unidentified receptor located presumably at the plasma membrane.

Plant cells may sense cold stress-induced changes in membrane fluidity and protein conformation. Cold stressinduced rigidification of the plasma membrane at microdomains may lead to actin cytoskeletal rearrangement, which may be followed by activation of $\mathrm{Ca}_{2}{ }^{+}$channels and increased cytosolic $\mathrm{Ca}_{2}{ }^{+}$level, triggering the expression of COR genes during cold acclimation (Sangwan et al., 2001; Chinnusamy et al., 2006). Current evidence suggests that cold stress may be perceived by plant cells through these changes in the plasma membrane fluidity state. Cold-induced calcium signaling is decoded and transduced by calcium sensory proteins $\left(\mathrm{Ca}_{2}{ }^{+}\right.$influx and $\mathrm{Ca}_{2}{ }^{+}$-dependent phosphorylation). Cold and other abiotic stresses induce reactive oxygen species that can activate a mitogen-activated protein kinase (MAPK) cascade. However, the molecular link between the kinases and transcription factors is still to be determined (Chinnusamy et al., 2006).

\section{Response of woody plants to cold stress: transcrip- tome, proteome and metabolome}

To get a better understanding of the process of plant cold tolerance and to develop strategies to improve resistance, genomic studies need to be complemented with studies of the transcriptome, proteome and metabolome (Renaut et al., 2006; Guy et al., 2008). While transcript studies provide valuable information, there is an increasing concern that the levels of mRNA transcripts are not always representative of cognate protein levels and that post-translational regulation also play an important role (Renaut et al., 2006). Advances in proteomic technologies have increased the utility of studying global changes in proteins to relate them with changes in gene expression "transcriptomic" and metabolism "metabolomic".

Proteomic studies have confirmed previous data on cold-inducible proteins obtained from one-dimensional SDS-PAGE or gene expression. Investigation is confined to specific tissues in herbaceous plants, while studies in woody trees studies are still limited. Populus and Prunus are some of the first genus studied in the later species (Renaut et al., 2006). Metabolomics provide a global profile of a wide array of metabolites whose levels are probably the result of enzyme activity and gene regulation at transcriptional level. The few initial applications of these emergent technologies help to identify novel metabolites and pathways not previously linked to cold stress (Gray et al., 2005; Guy et al., 2008). Gene expression changes in response to LT by increasing the levels of hundreds of metabolites, some of which are known to have protective effects (Zhu et al., 2007). The protective functions of metabolites, such as sucrose, trehalose, fructan, maltose, galactinol, glycine betaine and proline, are well documented in Arabidopsis, but generation of metabolomic data is in its infancy in woody plants. One aspect that is consistent across cold stress metabolomic studies is the role of carbohydrate metabolism, which seems to be a major feature of reprogramming of the metabolome by cold (Guy et al., 2008).

\section{CONCLUSIONS AND PERSPECTIVES}

Woody plants adjust their metabolism as the winter season progresses. In order to survive they have developed a complex dynamic mechanism by which plants enter a state of dormancy and become cold hardy, securing an accurate initiation and termination of winter metabolism.

At the end of the growing season, woody plants cease development and assume an increasing dormant and freezing-tolerant state, a strategy that protects them against a sudden arrival of winter. Activity of apical bud meristem ceases in response to decreasing photoperiod and temperatures, culminating in growth cessation and onset of dormancy. The degree of cold hardening varies in relation to the plant growth stage. Woody plants also begin to develop freezing tolerance as daylength and temperatures decrease, and a higher level of hardening is achieved by exposure to subzero temperatures, but cold hardiness decreases with increasing of temperatures in spring. Because winter dormancy and cold hardiness are overlapping events in plants, the processes involving them are difficult to distinguish and separate. This synchrony of growth with the seasons has received considerable attention, but 
the mechanisms are unresolved. In order to understand regulation of the cold tolerance of woody plants, it is essential to elucidate the complex interaction between dormancy and cold hardiness.

Recent molecular studies suggest that herbaceous annuals and woody plants share some similar mechanisms of cold tolerance; in fact Arabidopsis is being used to understand the role in herbaceous plants of genes obtained from woody species. A decrease in temperature induces the activation of comparable signaling processes and expression of related target genes. This similarity is evident in cold acclimation to short frost episodes during growth, but the process in woody plant is more complex due to a concomitant dormancy development. Rapid progress in understanding the molecular control of winter metabolism can be obtained through the novel approaches of functional genomics that are now being applied to woody plant studies. It is expected that the use of proteomics in the response of woody plants to LT will increase, providing a more complete representation of how plants respond to their environment. Future metabolomic studies of plant cold stress should reveal other metabolic pathways that have important functions in these mechanisms. There is no doubt that such a situation opens a wide horizon for future studies.

\section{BIBLIOGRAPHY}

Bergervoet J H W, H C Jing, J W E van den Hout, R Delmondez de Castro, B P A M Kunneman, R J Bino, S P C Groot (1999) Expression of beta-tubulin during dormancy induction and release in apical and axillary buds of five woody species. Physiol. Plant. 106:238-245.

Breton G, J Danyluk, F Ouellet, F Sarhan (2000) Biotechnological applications of plant freezing associated proteins. Biotech. Annu. Rev. 6:57-99.

Burke M J, R G Bryant, C J Weiser (1974) Nuclear magnetic resonance of water in cold acclimating red osier dogwood stem. Plant Physiol. 54:392-398.

Burr T J, L Otten (1999) Crown gall of grape: Biology and disease management. Annu. Rev. Phytopathol. 37:53-80.

Campalans A, M Pages, R Messeguer (2000) Protein analysis during almond embryo development. Identification and characterization of a late embryogenesis abundant protein. Plant Physiol. Biochem. 38:449-457.

Chalker-Scott L (1992) Disruption of an ice-nucleation barrier in cold hardy Azalea buds by sublethal heat stress. Ann. Bot. 70:409418 .

Chinnusamy V, J Zhu, J K Zhu (2006) Gene regulation during cold acclimation in plants. Physiol. Plant. 126:52-61.

Close, T J (1997) Dehydrins: A commonality in the response of plants to dehydration and low temperature. Physiol. Plant. 100:291 296.

Dhanaraj AL, J P Slovin, L J Rowland (2004) Analysis of gene expression associated with cold acclimation in blueberry floral buds using expressed sequence tags. Plant Sci. 166:863-872.

Dhanaraj A L, J P Slovin, L J Rowland (2005) Isolation of a cDNA clone and characterization of expression of the highly abun- dant, cold acclimation-associated $14 \mathrm{kDa}$ dehydrin of blueberry. Plant Sci. 168:949-957.

Diamant S, N Eliahu, D Rosenthal, P Goloubinoff (2001) Chemical chaperones regulate molecular chaperones in vitro and in cells under combined salt and heat stresses. J. Biol. Chem. 276:39586-39591.

Espinosa-Ruiz A, S Saxena, J Schmidt, E Mellerowicz, P Miskolczi, L Bako, R P Bhalerao (2004) Differential stage-specific regulation of cyclin-dependent kinases during cambial dormancy in hybrid aspen. Plant J. 38:603-615.

Faust M, D Liu, M M Millard, G W Stutte (1991) Bound versus free water in dormant apple buds. HortScience 26:887-890.

Ferullo J M, M Griffith (2001) Crop Responses and Adaptations to Temperature Stress. A.S. Basra (ed). The Haworth Press Inc., USA. $150 \mathrm{p}$.

Fuchigami L H, C C Nee (1987) Degree growth stage model and restbreaking mechanisms in temperate woody perennials. HortScience 22:836-845.

Garcia-Bañuelos M L, L Vazquez-Moreno, A A Gardea, J J Winzerling (2007) Characterization and expression of a dehydrin gene in apple tree (Malus domestica). NCBI: Entrez Nucleotide from BLAST, Accession \# DQ660905. NCBI: Entrez Protein from BLAST, Accession \# ABG56268. www.ncbi.nlm.nih.gov.

Gardea A A, P B Lombard, C H Crisosto, L W Moore, L H Fuchigami, L V Gusta (1992) Evaluation of frostgard, as an antifreeze, inhibitor of ice nucleators, and cryoprotectant of Pinot Noir leaf tissue. Am. J. Enol. Vitic. 44:232-235.

Gevaudant F, G Petel, A Guilliot (2001) Differential expression of four members of the Hb-ATPase gene family during dormancy and vegetative buds of peach trees. Planta 212:619 626.

Gray, G R, D Heath (2005) A global reorganization of the metabolome in Arabidopsis during cold acclimation is revealed by metabolic fingerprinting. Physiol. Plant. 124:236-248.

Greer D H, L A Robinson, A J Hall, K Klages, H Donnison (2000) Frost hardening of Pinus radiata seedlings: effects of temperature on relative growth rate, carbon balance and carbohydrate concentration. Tree Physiol. 20:107-114.

Gusta L V, R Trischuk, C J Weiser (2005) Plant Cold Acclimation: The Role of Abscisic Acid. J. Plant Growth Reg. 24:308 318.

Guy C L (1990) Cold acclimation and freezing stress tolerance: role of protein metabolism. Ann. Rev. Plant Physiol. Plant Mol. Biol. 41:187-223.

Guy, C, F Kaplan, J Kopka, J Selbig, D K Hincha (2008) Metabolomics of temperature stress. Physiol. Plant. 132:220 235 .

Hausladen A, R G Alscher (1994) Purification and characterization of glutathione reductase isozymes specific for the state of cold hardiness of red spruce. Plant Physiol. 105:205-213.

Heino P, G Sandman, V Lang, K Nordin, E T Palva (1990) Abscisic acid deficiency prevents development of freezing tolerance in Arabidopsis thaliana (L.) Heynh. Theor. Appl. Gen. 79:801806.

Horvath D P, J V Anderson, W S Chao, M E Foley (2003) Knowing when to grow: signal transduction processes regulating dormancy in vegetative buds. Trends Plant Sci. 8:534-540.

Jaglo K R, S Kleff, K L Amundsen, X Zhang, V Haake, J Z Zhang, T Deits, M F Thomashow (2001) Components of the Arabidopsis C-repeat/dehydration responsive element binding factor cold-response pathway are conserved in Brassica napus and other plant species. Plant Physiol. 127:910-917.

Junttila O, ̊̊ Kaurin (1990) Environmental control of cold acclimation in Salix pentandra. Scand. J. For. Res. 5:195-204. 
Kitashiba H, T Ishizaka, K Isuzugawa, K Nishimura, T Suzuki (2004) Expression of a sweet cherry DREB1/CBF ortholog in Arabidopsis confers salt and freezing tolerance. J. Plant Physiol. 161:1171-1176.

Kontunen-Soppela S, J Lankila., P Lahdesmaki, K Laine (2002) Response of protein and carbohydrate metabolism of Scots pine seedlings to low temperature. J. Plant Physiol. 159:175-180.

Lang G A, J D Early, G C Martin, R L Darnell (1987) Endo-, para-, and ecodormancy: physiological terminology and classification for dormancy research. HortScience 22:371-377.

Larcher W (2005) Climatic constraints drive the evolution low temperature resistance in woody plants. J. Agric. Meteor. 61:189202.

Levi A, G R Panta, C M Parmentier, M M Muthalif, R Arora, S Shanker, L J Rowland (1999) Complementary DNA cloning, sequencing and expression of an unusual dehydrin from blueberry floral buds. Physiol. Plant. 107:98-109.

Levitt J (1980) Responses of Plants to Environmental Stresses, 2nd ed, Vol. 1: Chilling, Freezing and High Temperature Stresses. Academic Press, New York, USA. 697 p.

Li C, T Puhakainen, A Welling, A Vihera-Aarnio, A Ernstsen, O Junttila, P Heino, E T Palva (2002) Cold acclimation in silver birch (Betula pendula). Development of freezing tolerance in different tissues and climatic ecotypes. Physiol. Plant. $116: 478-488$.

Lindow S E (1995) Control of epiphytic ice nucleation-active bacteria for management of plant frost injury. $I n$ : Biological Ice $\mathrm{Nu}-$ cleation and its Applications. R E Lee Jr, G J Warren, L V Gusta (eds).The Am. Phytopathol. Soc. St Paul, MN, USA. pp:239-256

Liu J J, A K M Ekramoddoullah, X Yu (2003) Differential expression of multiple PR10 proteins in western white pine following wounding, fungal infection and cold hardening. Physiol. Plant. 119:544-553.

Liu Q, M Kasuga, Y Sakuma, H Abe, S Miura, K YamaguchiShinozaki, K Shinozaki (1998) Two transcription factors, DREB1 and DREB2, with an EREBP/AP2 DNA binding domain, separate two cellular signal transduction pathways in drought and low temperature-responsive gene expression, respectively, in Arabidopsis. Plant Cell 10:1391-1406.

Lopez-Matas M-A, P Nuñez, A Soto, I Allona, R Casado, C Collada, MA Guevara, C Aragoncillo, L Gomez (2004) Protein cryoprotective activity of a cytosolic small heat shock protein that accumulates constitutively in chestnut stems and is up-regulated by low and high temperatures. Plant Physiol. 134:1708-1717.

Martz F, S Kiviniemi, E T Palva, M-L Sutinen (2006a) Contribution of omega-3 fatty acid desaturase and 3-ketoacyl-ACP synthase II (KASII) genes in the modulation of glycerolipid fatty acid composition during cold acclimation in birch leaves. J. Exp. Bot. 57:897-909.

Martz F, M-L Sutinen, S Kiviniemi, J P Palta (2006b) Changes in freezing tolerance, plasma membrane $\mathrm{H}^{+}$-ATPase activity and fatty acid composition in Pinus resinosa needles during cold acclimation and de-acclimation. Tree Physiol. 26:783-790.

Mattheis J P, D O Ketchie (1990) Changes in parameters of the plasmalemma ATPase during cold acclimation of apple (Malus domestica) tree bark tissues. Physiol. Plant. 78:616-622.

McNeil S D, M L Nuccio, A D Hanson (1999) Betaines and related osmoprotectants: targets for metabolic engineering of stress resistance. Plant Physiol. 120:945-949.

Muthalif M M, L J Rowland (1994) Identification of dehydrin-like proteins responsive to chilling in floral buds of blueberry (Vaccinium, section Cyanococcus). Plant Physiol. 104:143947
Nasholm T, A Ericsson (1990) Seasonal changes in amino acids, protein and total nitrogen in needles of fertilized Scots pine trees. Tree Physiol. 6:267-281.

Owens C L, M F Thomashow, J F Hancock, A F Iezzoni (2002) CBF orthologs in sour cherry and strawberry and the heterologous expression of CBF1 in strawberry. J. Am. Soc. Hort. Sci 127:489-494.

Puhakainen T, M W Hess, P Makela, J Svensson, P Heino, E T Palva (2004a) Overexpression of multiple dehydrin genes enhances tolerance to freezing stress in Arabidopsis. Plant Mol. Biol. 54:743-753.

Puhakainen T, C Li, M Boije-Malm, J Kangasjarvi, P Heino, E T Palva (2004b) Short-day potentiation of low temperatureinduced gene expression of a C-repeat-binding factorcontrolled gene during cold acclimation in silver birch. Plant Physiol. 136:4299-4307.

Ramos A, E Perez-Solıs, C Ibanez, R Casado, C Collada, L Gomez, C Aragoncillo, I Allona (2005) Winter disruption of the circadian clock in chestnut. Plant Biol. 102:7037-7042.

Renaut J, J F Hausman, M Wisniewski (2006) Proteomics and low temperature studies: bridging the gap between gene expression and metabolism. Physiol. Plant. 126:97-109.

Repo T, G Zhang, A Ryyppo, R Rikala, M Vuorinen (2000) The relation between growth cessation and frost hardening in Scots pines of different origins. Trees 8:456-464.

Rinne P L H, P M Kaikuranta, C van der Schoot (2001) The shoot apical meristem restores its symplasmic organization during chilling-induced release from dormancy. Plant J. 26:249-264.

Rohde A, E Prinsen, R De Rycke, G Engler, M Van Montagu, W Boerjan (2002) PtABI3 impinges on the growth and differentiation of embryonic leaves during bud set in poplar. Plant Cell 14:1885-1901.

Sangwan V, I Foulds, J Singh, R J Dhindsa (2001) Cold activation of Brassica napus BN115 promoter is mediated by structural changes in membranes and cytoskeleton, and requires $\mathrm{Ca} 2+$ influx. Plant J. 27:1-12.

Siller-Cepeda J H, L H Fuchigami, T H H Chen (1992) Glutathione content in peach buds in relation to development and release of rest. Plant Cell Physiol. 33:867-872.

Thomashow M F (1999) Plant cold acclimation: freezing tolerance genes and regulatory mechanisms. Ann. Rev. Plant Physiol. Plant Mol. Biol. 50:571-599.

Ukaji N, C Kuwabara, D Takezawa, K Arakawa, S Fujikawa (2001) Cold acclimation-induced WAP27 localized in endoplasmic reticulum in cortical parenchyma cells of mulberry tree was homologous to group 3 late-embryogenesis abundant proteins. Plant Physiol. 126:1588-1597.

Ukaji N, C Kuwabara, D Takezawa, K Arakawa, S Fujikawa (2004) Accumulation of pathogenesis-related (PR) 10/ Bet v 1 protein homologues in mulberry (Morus bombycis Koidz.) tree during winter. Plant Cell and Environ. 27:1112-1121.

Ukaji N, C Kuwabara, D Takezawa, K Arakawa, S Yoshida, S Fujikawa (1999) Accumulation of small heat-shock protein homologs in the endoplasmic reticulum of cortical parenchyma cells in mulberry in association with seasonal cold acclimation. Plant Physiol. 120:481-490.

Vertucci C W (1990) Calorimetric studies of the state of water in seed tissues. Biophysical J. 58:1463-1471.

Wang W, B Vinocur, A Altman (2003) Plant responses to drought, salinity and extreme temperatures: towards genetic engineering for stress tolerance. Planta 218:1-14.

Weiser C J (1970) Cold resistance and injury in woody plants. Science 169:1269-1278

Welling A, E T Palva (2006) Molecular control of cold acclimation in trees. Physiol. Plant. 127:167-181. 
Welling, A, P Rinne, A Vihera-Aarnio, S Kontunen-Soppela, P Heino, E Palva (2004) Photoperiod and temperature differentially regulate the expression of two dehydrin genes during overwintering of birch (Betula pubescens Ehrh). J. Exp. Bot. 55:507-516

Wisniewski M E, C Bassett, J Renaut, R Farrell, T Tworkoski, T S Artlip (2006) Differential regulation of two dehydrin genes from peach (Prunus persica) by photoperiod, low temperature and water deficit. Tree Physiol. 26:575-584.

Wisniewski M, C Bassett, R Arora (2004) Distribution and partial characterization of seasonally expressed proteins in different aged shoots and roots of 'Loring' peach (Prunus persica). Tree Physiol. 24:339-345.
Yakubov B, O Barazani, A Shachack, L J Rowland, O Shoseyov, A Golan-Goldhirsh (2005) Cloning and expression of a dehydrin-like protein from Pistacia vera L. Trees 19:224-230.

Yamaguchi R, M Nakamura, N Mochizuki, S A Kay, A Nagatani (1999) Light-dependent translocation of a phytochrome BGFP fusion protein to the nucleus in transgenic Arabidopsis. J. Cell Biol. 145:437-445.

Yu X, A K M Ekramoddoullah, S Misra (2000) Characterization of Pin $\mathrm{m}$ III cDNA in western white pine. Tree Physiol. 20:663-671.

Zhu J, C-H Dong, J-K Zhu (2007) Interplay between cold-responsive gene regulation, metabolism and RNA processing during plant cold acclimation. Curr. Op. Plant Biol. 10:290-295. 